\title{
ERP Support for Lean Production
}

\author{
Daryl Powell", Erlend Alfnes, \\ Jan Ola Strandhagen, and Heidi Dreyer \\ Department of Production and Quality Engineering, \\ Norwegian University of Science and Technology, \\ Trondheim, Norway, \\ SINTEF Technology and Society, Trondheim, Norway \\ daryl.j.powell@ntnu.no
}

\begin{abstract}
In the traditional sense, IT has often been viewed as a contributor to waste within lean production. However, as the business world changes and competition from low-cost countries increases, new models must be developed which deliver competitive advantage by combining contemporary technological advances with the lean paradigm. By applying an action research approach, this paper evaluates the support functionality of ERP systems for lean production. We address the fundamental principles of lean production in comparison with the functionality and modules of a contemporary ERP system.
\end{abstract}

Keywords: Lean production, Enterprise resource planning, Action research.

\section{Introduction}

Though the theory of lean production is nowadays well understood, the relationship between information technology (IT) and lean production remains a controversial and far less explored topic. While lean is often characterized by decentralized coordination and control, ITs such as enterprise resource planning (ERP) systems are typically best suited to support centralized production planning. However, Powell and Strandhagen (2011) identify and explore the lean-ERP paradox, and suggest that there is a synergistic impact to be realised in combining ERP systems within the lean paradigm. Riezebos et al. (2009) also argue that modern IT can indeed be tailored to support lean, but state that further research is required to evaluate the combination of lean production principles and ERP. Therefore, the purpose of this paper is to evaluate the support functionality of a contemporary ERP system for lean production by addressing the following research question:

\section{How can a contemporary ERP system be used to support lean production principles?}

\footnotetext{
* Corresponding author. 


\section{Theoretical Background}

The term lean production was popularized by Womack et al. (1990) when they compared the mass production principles of the Western world to the very simple production principles of Toyota. However, this philosophy was primarily directed at the organization and less on information technologies (Zuehlke, 2010). As such, IT has since been viewed as a contributor to the waste to be eliminated, rather than as a tool to help achieve and sustain positive change (Bell, 2006). The increasing rate of development of IT today is constantly increasing manufacturing companies' ability to react quickly and reliably to demand through increased transparency, visualization and processing capabilities. Moody (2006) suggests that, although profitability can be enhanced in any number of ways, one of the most rewarding and direct avenues is through the use of technology. Riezebos et al. (2009) suggest that modern IT (such as contemporary ERP systems) can be tailored to support lean production.

ERP is one of the most widely accepted choices to obtain competitive advantage for manufacturing companies (Zhang et al., 2005). ERP systems are designed to provide seamless integration of processes across functional areas with improved workflow, standardization of various business practices, and access to real-time data (Mabert et al., 2003). The fundamental benefits of ERP systems do not in fact come from their inherent "planning" capabilities but rather from their abilities to process transactions efficiently and to provide organized record keeping structures for such transactions (Jacobs and Bendoly, 2003).

In order to evaluate the support functionality offered by ERP systems for lean production, we use the fundamental principles of lean manufacturing identified by Womack and Jones (1996): "precisely specify value by specific product; identify the value stream for each product; make value flow without interruptions; let the customer pull value from the producer; and pursue perfection" (Hines, 2010).

By conducting a study of the extant literature in the form of academic journals, trade journals, textbooks, and white papers; we identify 15 fundamental areas in which an ERP system could be configured to support lean production principles. The 15 areas, which we call the 15 keys to ERP support for lean, are summarized in Table 1:

Table 1. 15 keys to ERP support for lean production

\begin{tabular}{|l|l|l|l|}
\hline No & Principle & An ERP system for lean production should: & Reference: \\
\hline $\mathbf{1}$ & \multirow{2}{*}{ Value } & Support customer relationship management & $\begin{array}{l}\text { (Chen and Popovich, } \\
\text { 2003) }\end{array}$ \\
\cline { 4 - 5 } $\mathbf{2}$ & & $\begin{array}{l}\text { Automate necessary non-value adding activities } \\
\text { (e.g. backflushing) }\end{array}$ & (Hamilton, 2009) \\
\hline \multirow{3}{*}{$\begin{array}{l}\text { Value } \\
\text { stream }\end{array}$} & $\begin{array}{l}\text { Enable process-modelling to support standard } \\
\text { work processes }\end{array}$ & $\begin{array}{l}\text { (IFS, 2008, Prediktor, } \\
\text { Provide a source for easy-to-find product } \\
\text { drawings and standard work instructions }\end{array}$ & $\begin{array}{l}\text { (Houy, 2005, } \\
\text { Tjahjono, 2009) }\end{array}$ \\
$\mathbf{5}$ & $\begin{array}{l}\text { Support information sharing across the supply } \\
\text { chain }\end{array}$ & $\begin{array}{l}\text { (Bjorklund, 2009, } \\
\text { Koh et al., 2008) }\end{array}$ \\
\hline
\end{tabular}


Table 1. (continued)

\begin{tabular}{|c|c|c|c|}
\hline 6 & \multirow{5}{*}{ Flow } & $\begin{array}{l}\text { Create synchronized and streamlined data flow } \\
\text { (internal \& external) }\end{array}$ & (Hamilton, 2003) \\
\hline 7 & & Support line balancing & $\begin{array}{l}\text { (Steger-Jensen and } \\
\text { Hvolby, 2008) }\end{array}$ \\
\hline 8 & & Support demand levelling & (Hamilton, 2009) \\
\hline 9 & & $\begin{array}{l}\text { Support orderless rate-based planning } \\
\text { (e.g. takt-time) }\end{array}$ & (IFS, 2010) \\
\hline 10 & & $\begin{array}{l}\text { Provide decision support for shop floor deci- } \\
\text { sion making }\end{array}$ & (Hamilton, 2009) \\
\hline 11 & \multirow{3}{*}{ Pull } & Support kanban control & $\begin{array}{l}\text { (Hamilton, 2009, } \\
\text { Masson and Jacobson, } \\
\text { 2007) }\end{array}$ \\
\hline 12 & & Support production levelling (Heijunka) & $\begin{array}{l}\text { (Masson and } \\
\text { Jacobson. 2007) }\end{array}$ \\
\hline 13 & & Support JIT procurement & $\begin{array}{l}\text { (Masson and } \\
\text { Jacobson, 2007) }\end{array}$ \\
\hline 14 & \multirow{2}{*}{ Perfection } & $\begin{array}{l}\text { Provide a system to support root-cause analy- } \\
\text { sis and for the logging and follow-up of quality } \\
\text { problems }\end{array}$ & (Bjorklund, 2009) \\
\hline 15 & & $\begin{array}{l}\text { Provide highly visual and transparent opera- } \\
\text { tional measures (e.g. real time status against } \\
\text { plan) }\end{array}$ & (Prediktor, 2010) \\
\hline
\end{tabular}

\section{Research Methodology}

In this study we adopt an action research approach by following an ERP implementation project at a case company in Trondheim, Norway. One of the authors has been actively involved at the case company during the introduction of lean practices since 2009 , and has also been present during the design and analysis phase of the ERP implementation process since January 2011.

\section{Action Research}

Philips (2004) suggests that there is a broad Scandinavian tradition for action research. Action research can be defined as a participatory, democratic process concerned with developing practical knowing in the pursuit of worthwhile human purposes, grounded in a participatory worldview (Reason and Bradbury, 2006). Essentially, it focuses on bringing about change (action) and contributing to knowledge (research). McNiff and Whitehead (2009) suggest that doing action research involves the following:

1. Taking action (changing something);

2. Doing research (analyzing and evaluating both the change and change process);

3. Telling the story and sharing your findings (disseminating the results).

Action research is considered as an appropriate methodology for this study as both lean production and ERP systems are very much applied in industry, thus a "learning by doing" approach is very suitable. 


\section{Client System: Noca AS}

Noca is a manufacturing and service supplier within electronics and electronics development. Established in 1986, Noca delivers development, prototypes, batch production, and assembly for customers within innovation and entrepreneurs in hightech industries. Noca has 50 employees and an annual turnover of $€ 11.5 \mathrm{~m}$ (2010). The company is currently actively applying lean practices to their operations, having started with value stream mapping (VSM) in 2009, followed by $5 \mathrm{~S}$ in 2010 . Noca has also identified a need to enhance their supporting processes, such as production planning and control, and have therefore chosen to implement a new ERP system, Jeeves Universal (Figure 1). Recognised as "Sweden's most popular ERP system 2009", Jeeves Universal is claimed to be a flexible (customized) standard ERP system (ERPResearch.org, 2010). The ERP implementation process at Noca will consist of three phases - a design and analyse phase (phase zero); an implementation phase (phase one); and an improvement phase (phase two). This paper considers phase zero only.

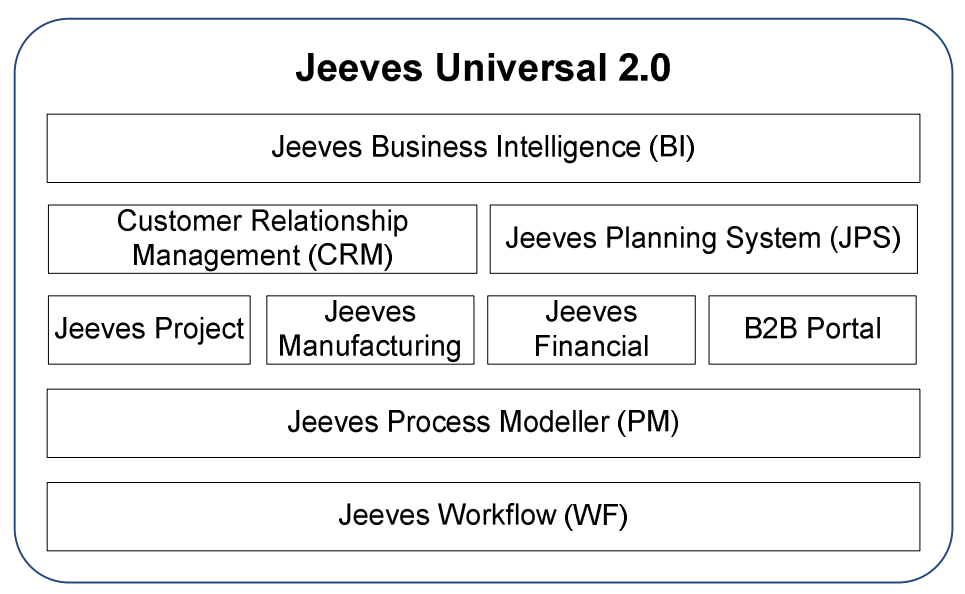

Fig. 1. The "Jeeves Universal" ERP system and selected modules

\section{Results}

This paper presents preliminary findings following phase zero of the ERP implementation project, which we call the design and analysis phase. By evaluating the functionality of the chosen ERP system and selected modules (Figure 1) against the lean principles identified by Womack and Jones (1996), we are able to propose a theoretical framework for ERP support for lean production (Figure 2). This framework can be used by researchers and practitioners when combining lean and ERP. 


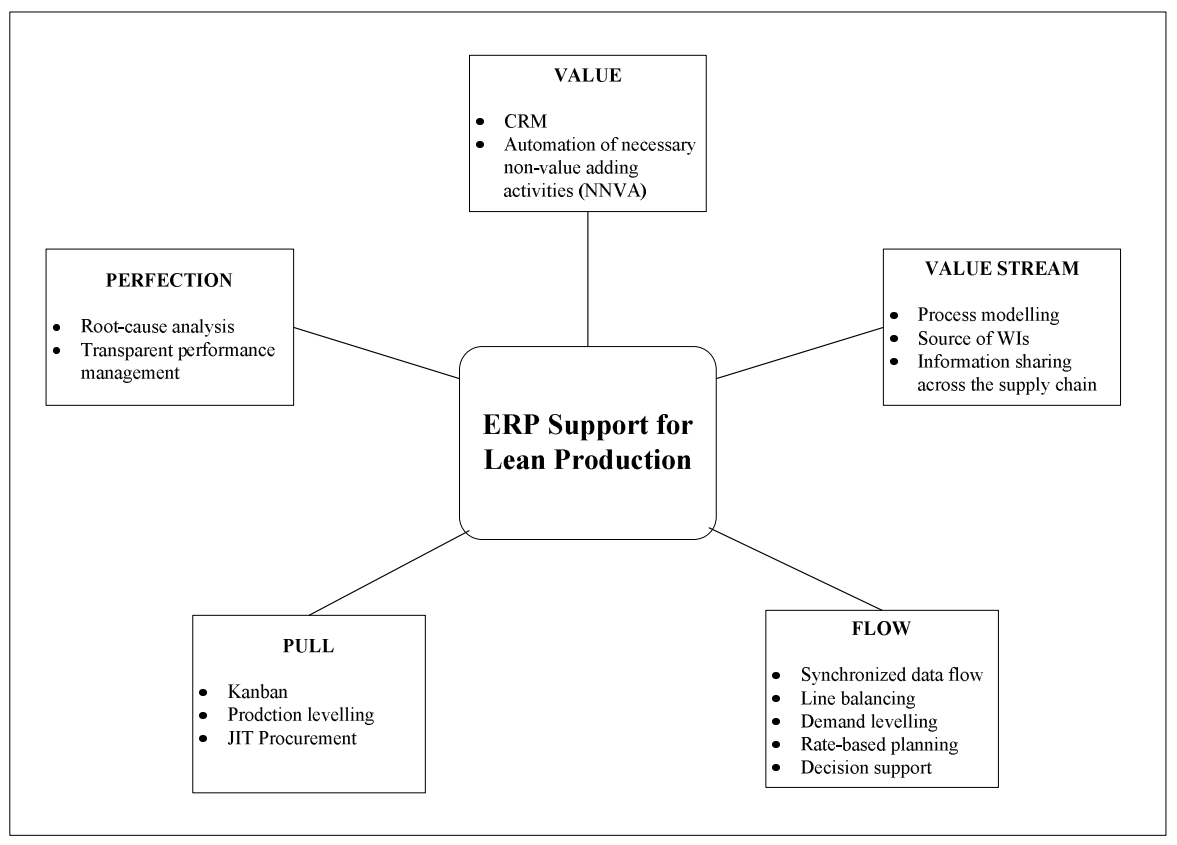

Fig. 2. ERP Support for Lean Production - a Conceptual Framework

\section{Value}

It was identified that a significant element of the ERP system that helps contribute to value creation from the point of view of the customer was the application of a customer relationship management (CRM) module. The ERP system also offered select functionality to automate the necessary, non-value adding activities, such as backflushing (e.g. Hamilton, 2003).

\section{Value Stream}

In terms of supporting the value stream, it was shown that the ERP system offered process modelling functionality to support the creation of standard work processes, as well as providing a source for easy-to-find product drawings and work instructions. Functionality that enables the sharing of information across the supply chain is also offered with the B2B Portal. The ERP system also supports a number of different levels within the factory, ranging from the individual operation (process level), through production group (work cell level), to flow group (value stream level).

\section{Flow}

The main module of the ERP system supporting flow manufacturing was identified as the Workflow (WF) module, which integrated all functions of the enterprise and aided the creation of a "paperless" paper-trail for continuous flow of information supporting the production processes. Functionality is also offered to support line balancing; demand levelling; and orderless rate-based planning through the use of Jeeves planning 
system (JPS). Finally, and particularly through the use of business intelligence (BI), decision support for shopfloor decision making allows shopfloor workers to become even more empowered in the lean environment.

\section{Pull}

Even though the client system is too early in its lean journey to implement a pull system, ERP support for pull production was still taken into consideration. It was noted in particular that the JPS is a very useful visual tool that can be used to support production levelling (heijunka). It is also anticipated that the WF module can be used to support pull production through enabling and supporting material and information flow. JIT procurement can be supported through integrating a product's BOM within both Jeeves Project (for prototyping and ramp-up) and Jeeves manufacturing (for volume production).

\section{Perfection}

Finally, in terms of perfection and continuous improvement, it was highlighted how the ERP system can make use of both BI and JPS (as a visual tool) to provide a system for logging and follow-up of quality problems, and to provide a system for highly visual and transparent operational measures.

\section{Conclusion}

By considering the functionality of the Jeeves Universal ERP system against the five lean principles, we conceptualized a framework for ERP support for lean production, which we call "the 15 keys to ERP support for lean production". The framework (shown in Table 1) highlights the theoretical support functionality of the Jeeves Universal ERP system for lean production. This can be used by researchers and practitioners for the future integration of ERP systems within the lean paradigm.

Though measures have been taken to increase the validity of this research, a number of limitations do however exist. For example, a commonly cited limitation of the action research approach is the focus upon only one company. Though it is often not the main goal of action research to generalise results, the results herein can be used as a template for reflecting on new experience (Friedman, 2010). We also only considered an ERP system of one single vendor, Jeeves. We suggest that further investigation with other case companies and/or other ERP system vendors would help to make our framework more generalizable.

A particularly interesting subject that arose as a result of the work was ERP support for pull production. Therefore, the authors suggest that a greater focus should be taken on the role of ERP systems in helping manufacturers to realise JIT production, one of the most important dimensions of lean. Further work should therefore investigate ERP support for pull production, helping to strengthen the validity and contribution of this work. 


\section{References}

Bell, S.: Lean Enterprise Systems: Using IT for Continuous Improvement. Wiley and Sons, Hoboken (2006)

Bjorklund, J.: 10 Ways to Use ERP to Lean the Manufacturing Supply Chain. Managing Automation (2009), http://www.managingautomation.com/uploadedimages / downloads/10_Ways_ERP_Lean_Manuf.pdf (accessed September 2010)

Chen, I.J., Popovich, K.: Understanding customer relationship management (CRM). People, process and technology. Business Process Management Journal 9, 672-688 (2003)

Erpresearch.org. What is Jeeves Universal ERP? (2010), http: / / octavesolutions. com/erpresearch / ?p=5 (accessed June 2011)

Friedman, V.J.: Action Science: Creating Communities of Inquiry in Communities of Practice. In: Reason, P., Bradbury, H. (eds.) The Handbook of Action Research. Sage, London (2010)

Glenday, I., Sather, R.: Breaking Through to Flow (2005), http: //www. leanuk.org/ downloads/LFL_2005/Day2_Plenary_Glenday_Sather.pdf (accessed May 2009)

Hamilton, S.: Maximizing your ERP system: a practical guide for managers. McGraw Hill, New York (2003)

Hamilton, S.: Managing Lean Manufacturing using Microsoft Dynamics. McGraw Hill, New York (2009)

Hines, P.: The Principles of the Lean Business System. S A Partners (2010), http:// www. sapartners. com/images / pdfs / the $\% 2$ principles $\% 20$ of $\% 20$ the $\% 20$ lean $\% 20$ business $\% 20$ system.pdf (accessed February 2011)

Houy, T.: ICT and Lean Management: Will They Ever Get Along (2005), http: / /mpra.ub.uni-muenchen.de/2502/ (accessed September 2010)

IFS. Going Lean, Step by Step, with IFS Applications (2008), http: / / www. manmonthly. com.au/Article/Going-Lean-Step-by-Stepwith-IFS-Applications (accessed September 2009)

IFS. IFS Applications for Lean manufacturing. IFS AB (2010)

Jacobs, F.R., Bendoly, E.: Enterprise resource planning: Developments and directions for operations management research. European Journal of Operational Research 146, 233-240 (2003)

Koh, S.C.L., Gunasekaran, A., Rajkumar, D.: ERP II: The involvement, benefits and impediments of collaborative information sharing. International Journal of Production Economics 113, 245-268 (2008)

Mabert, V.A., Soni, A., Venkataramanan, M.A.: Enterprise resource planning: Managing the implementation process. European Journal of Operational Research 146, 302-314 (2003)

Masson, C., Jacobson, S.: Lean Planning and Execution Software: Extending Lean Thinking Across the Enterprise (2007), http://www.oracle.com/corporate/analyst/ reports/industries/aim/amr-20378.pdf (accessed September 2010)

Mcniff, J., Whitehead, J.: Doing and Writing Action Research. Sage, Los Angeles (2009)

Moody, P.E.: With Supply Management, Technology Rules! Supply Chain Management Review (May/June 2006)

Philips, M.E.: Action research and development coalitions in health care. Action Research 2, 349-370 (2004)

Powell, D., Strandhagen, J.O.: Lean Production Vs. ERP Systems: An ICT Paradox? Operations Management 37, 31-36 (2011)

Prediktor. Lean (2010), http://www.prediktor.no/business_solutions/ lean/Pages / default . aspx (accessed February 2011)

Reason, P., Bradbury, H. (eds.): Handbook of Action Research. Sage Publications, London (2006) 
Riezebos, J., Klingenberg, W., Hicks, C.: Lean Production and information technology: Connection or contradiction? Computers in Industry 60, 237-247 (2009)

Steger-Jensen, K., Hvolby, H.-H.: Review of an ERP System Supporting Lean Manufacturing. In: Koch, T. (ed.) Lean Business Systems and Beyond. IFIP AICT, vol. 257, pp. 67-74. Springer, Boston (2008)

Tjahjono, B.: Supporting shop floor workers with a multimedia task-oriented information system. Computers in Industry 60, 257-265 (2009)

Womack, J.P., Jones, D.T.: Lean Thinking: Banish Waste and Create Wealth in Your Corporation. Simon and Schuster, New York (1996)

Womack, J.P., Jones, D.T., Roos, D.: The Machine that Changed the World. Harper Perennial, New York (1990)

Zhang, Z., Lee, M.K.O., Huang, P., Zhang, L., Huang, X.: A framework of ERP systems implementation success in China: An empirical study. International Journal of Production Economics 98, 56-80 (2005)

Zuehlke, D.: SmartFactory - Towards a factory-of-things. Annual Reviews in Control 34, 129138 (2010) 